\title{
Bacterial Tolerance to Heavy Metal Contents Present in Contaminated and Uncontaminated Soils
}

\author{
F. Z. Tanu and S. Hoque*
}

\begin{abstract}
Present study dealt with identification of some heavy metal tolerant bacteria from contaminated industrial soils of Dhaka Export Processing Zone (DEPZ) at Savar, tannery area at Hazaribagh and uncontaminated agricultural soils of Dhamrai and Kushtia in Bangladesh and determination of their tolerance to chromium $\left(\mathrm{Cr}^{6+}\right)$ and cadmium $\left(\mathrm{Cd}^{2+}\right)$. A total of 15 isolates from four soil samples were provisionally identified as different species of Bacillus, Micrococcus and Pseudomonas based on their morphological, physiological, and biochemical characteristics. Among them eight colonies were separated based on high level of heavy metal tolerance and identified at molecular level by PCR technique and 16S rRNA gene sequencing as Micrococcus luteus strain P43 (E4), Bacillus pocheonensis strain TR2-6 (T6), Bacillus megaterium strain H2 (T8), Bacillus amyloliquefaciens strain SCSAAB0007 (D10), Bacillus cereus isolate PGBw4 (D11), Bacillus cereus strain ES-4a1 (K12), Bacillus subtilis strain 1320, (K13), and Bacillus subtilis strain DP14 (K14). The Maximum Tolerable Concentration (MTC) of bacterial strains to $\mathrm{Cr}^{6+}$ and $\mathrm{Cd}^{2+}$ ranged between $250-1250 \mu \mathrm{g} / \mathrm{ml}$ and $30-150 \mu \mathrm{g} / \mathrm{ml}$, respectively in nutrient broth medium. From the metal tolerance investigation Bacillus was found as the most heavy metal tolerant to both $\mathrm{Cr}^{6+}$ and $\mathrm{Cd}^{2+}$ among the three genera. The identified heavy metal tolerant bacteria could be useful for the bioremediation of heavy metal contaminated environment.
\end{abstract}

Key Words: Heavy metal tolerance, MTC, Soil bacteria, Contaminated and uncontaminated soils.

\section{Introduction}

Heavy metal pollution of soil and wastewater is a significant environmental problem ${ }^{1}$. In recent decades, the discharge of industrial effluents without proper treatment into soil and water bodies from different natural and anthropogenic sources containing heavy metals has resulted a serious threat to public health because of their persistence, bio-magnification, and accumulation in food chain. Most of the heavy metals like chromium, cadmium, lead, mercury and copper are highly toxic for almost all the living organisms. Each heavy metal has unique bio-functions or bio-toxicities. To investigate heavy metal tolerance of soil bacteria $\mathrm{Cr}$ and $\mathrm{Cd}$ were selected in this study based on the fact that these metals are two of important pollutants of industrial areas.

Hexavalent chromium $\mathrm{Cr}(\mathrm{VI})$ and trivalent chromium $\mathrm{Cr}(\mathrm{III})$ are the most prevalent species of chromium in the natural environment ${ }^{2}$ and the former is more toxic for microorganisms. Major sources of $\mathrm{Cr}$ pollution include effluents from leather tanning, Cr electroplating, wood preservation, alloy preparation, and nuclear wastes due to its use as a corrosion inhibitor in nuclear power plants ${ }^{3}$. Cadmium is one of the most toxic pollutants of the surface soil layer, released into the environment by mining and smelting activities, atmospheric deposition from metallurgical industries, incineration of plastics and batteries, land application of sewage sludge, and burning of fossil fuels ${ }^{4}$.
In the contaminated sites, bacteria are continuously exposed to different heavy metals, thus giving rise to survival of metal tolerant strains. To survive under metal-stressed conditions, microorganisms have acquired a variety of mechanisms for adaptation to the presence of toxic heavy metals ${ }^{5}$. Microbes play massive role in the biogeochemical cycling of toxic heavy metals and also in cleaning up or remediating metalcontaminated environments. Since soil is one of the most important environments for microbes and is easily exposed to many pollutants, evaluating the effects of pollutants on the microbial population is much valuable. There is increasing evidence for the evolution of metal tolerance in natural populations inhabiting contaminated sites ${ }^{6}$. Toxic metal tolerance in bacteria have been studied for many years but considering the range of toxic metal ions and diversity of microbes, the overall efforts appear to be limited. Therefore this study was performed to determine the heavy metal tolerance of bacteria which were isolated from metal contaminated and uncontaminated soils.

\section{Materials and Methods \\ Collection of soil samples}

A total of four soil samples were collected, two from contaminated sites of DEPZ, Savar and tannery area, Hazaribagh, and two from uncontaminated agricultural sites of Dhamrai and Kushtia from the surface $(0-15 \mathrm{~cm}$ depth) in plastic bags aseptically. 


\section{Isolation of bacteria}

For the isolation of bacteria serial dilution plate technique was carried out ${ }^{7}$. Subsequent dilutions were made up to $10^{5}$ times and each sample was spread over the surface of nutrient agar plates in duplicate. Plates were incubated at $37^{\circ} \mathrm{C}$ for 72 hours in an incubator and colonies differing in morphological characteristics were selected and used for further studies. Three consecutive streaking of each culture were done to ensure purity of the strains.

\section{Preparation of metal solution}

Analytical grades of metal salts of $\mathrm{K}_{2} \mathrm{Cr}_{2} \mathrm{O}_{7}$ and $\mathrm{CdCl}_{2} \cdot 2.5 \mathrm{H}_{2} \mathrm{O}$ were used to prepare $5000 \mu \mathrm{g} / \mathrm{ml}$ stock solutions of $\mathrm{Cr}$ and $\mathrm{Cd}$, respectively. Each stock solution was ûlter-sterilized and added to nutrient broth at varying concentrations of metals to determine the $\mathrm{MTC}^{8}$.

Preliminary screening of Chromium and Cadmium tolerant bacteria

The screening of previously isolated soil bacterial populations tolerant to $\mathrm{Cr}^{6+}$ and $\mathrm{Cd}^{2+}$ ions was carried out by streaking of the culture on nutrient agar plates supplemented with different concentrations of two metal ions as $0,100,300,500,1000$, 1200, and $1500 \mu \mathrm{g} / \mathrm{ml}$ of $\mathrm{Cr}^{6+}$, and 0, 30, 50, 75, 100, 150, 200, and $250 \mu \mathrm{g} / \mathrm{ml}$ of $\mathrm{Cd}^{2+}$, separately. All plates in duplicates were incubated at $37^{\circ} \mathrm{C}$ for 3 days to confirm their abilities to grow at high concentrations of $\mathrm{Cr}^{6+}$ and $\mathrm{Cd}^{2+}$ containing media. After the incubation period the concentration at which bacterial growth was present indicated bacterial tolerance to that concentration. The isolated and distinct colonies on the medium were subcultured repeatedly using same medium for purification.

Morphological, physiological, and biochemical characterization of the isolates

The characters of the organisms were studied using standard microbiological methods followed by Sneath et al. ${ }^{9}, \mathrm{SAB}^{10}$, Cappuccino and Sherman ${ }^{11}$, Collins and Lyne ${ }^{12}$, and Claus ${ }^{13}$. Colony characters such as the color, form, optical feature, margin, elevation and the shape and arrangements of vegetative cells after Gram staining ${ }^{14}$ were observed under a phase contrast microscope from 20h old culture grown on solidified agar plates. The physiological and biochemical characters viz. motility, gelatin liquefaction, starch hydrolysis, indole production, oxygen requirement, oxidase test, catalase test, MRVP test, deamination of phenylalanine, acid and gas production from D-glucose, and citrate utilization were studied.

\section{Identification of the isolates}

The isolates were tested and characterized by several microbiological key conventional tests for basic differentiation of Gram-negative and Gram-positive bacteria as described in Bergey's Manual of Determinative Bacteriology ${ }^{15}$. Further, the isolates were identified on the basis of biochemical tests of commercial identification systems according to Bergey's Manual of Systematic Bacteriology (Vol. 2) ${ }^{9}$.
Identification of the isolates by PCR and 16S rRNA gene sequencing

In order to identify the isolates based on sequence comparison, partial amplification of 16S rRNA gene was done using the primer pairs of 5'-16S rRNA: CCAGACTCC TACGGGAGGCAGC and 3'-16S rRNA: CTTGTGCGGG CCCCCGTCAATTC. Polymerase Chain Reaction (PCR) products purified through alcohol precipitation were sequenced directly using a DNA auto sequencer (Applied Bio-system 3130) using the bacterial universal primers $27 \mathrm{f}$ and $1492 \mathrm{r}$. To prepare PCR cocktail (total $400 \mu$ for 8 samples) sterile deionized distilled water $(304 \mu \mathrm{l})$, taq buffer B 10X (40 $\mu \mathrm{l}), \mathrm{MgCl}_{2}(24$ $\mu \mathrm{l})$, primer forward $(4 \mu \mathrm{l})$, primer reverse $(4 \mu \mathrm{l})$, dNTPs $10 \mathrm{mM}$ ( $4 \mu \mathrm{l})$, taq DNA polymerase $5 \mathrm{U} / \mu \mathrm{l}(4 \mu \mathrm{l})$, and template DNA 25 $\mathrm{ng} / \mu \mathrm{l}(16 \mu \mathrm{l})$ were used ${ }^{16}$. The sequence generated from automated sequencing of PCR amplified DNA was analyzed through NCBI BLAST (http://blast.ncbi.nlm.nih.gov/) program to find out possible similar organism through alignment of homologous sequences in the NCBI databank.

\section{Estimation of bacterial tolerance to metals by MTCs}

For evaluation of the MTC of $\mathrm{Cr}^{6+}$ and $\mathrm{Cd}^{2+}$ of 8 bacterial isolates, nutrient broth medium in screw cap tubes with different concentrations of each metal $\left(\mathrm{Cr}^{6+}\right.$ ranging from 200 to 1300 $\mu \mathrm{g} / \mathrm{ml}$ and $\mathrm{Cd}^{2+}$ ranging from 15 to $200 \mu \mathrm{g} / \mathrm{ml}$ ) were prepared and the bacteria were cultured readily in that tubes and kept in an incubator for 48 hours. Each liquid sample of isolates was spreaded over agar plates in duplicate and inoculated at $37^{\circ} \mathrm{C}$ for 24-72h to test the appearance of growth. The presence of growth of bacterial culture was determined visually as positive or negative. The absence of bacterial growth indicated its sensitivity, while the presence of growth at certain metal concentration indicated that bacteria were tolerant to that concentration.

\section{Results}

Isolation and screening of metal tolerant bacteria

The fifteen bacterial isolates differentiated based on differences in colonial morphology were designated as mentioned in Table 1 and eight of them (E4, T6, T8, D10, D11, K12, K13, and K14) were selected as Chromium $\left(\mathrm{Cr}^{6+}\right)$ and Cadmium $\left(\mathrm{Cd}^{2+}\right)$ tolerant bacteria.

\section{Colonial morphology}

The colonial forms of all bacteria were circular; elevations were convex, effuse, and umbonate; colonial margins were regular, erose, entire, and undulate type; colonial surfaces were smooth, concentric, and rough; the colors of the colonies were yellow, brown, off-white, white, orange, and light pink. Detailed results for colonial morphology are presented in Table 2. 
Table 1: Chromium $\left(\mathrm{Cr}^{6+}\right)$ and Cadmium $\left(\mathrm{Cd}^{2+}\right)$ tolerant bacterial samples isolated from contaminated and uncontaminated soils

\begin{tabular}{lc}
\hline Location of Soil Sample & Bacterial sample \\
\hline DEPZ, Savar & E1 \\
& E2 \\
& E3 \\
Tannery Area, Hazaribagh & E4 \\
& T5 \\
Agricultural fields of Dhamrai & T6 \\
& T7 \\
Agricultural fields of Kushtia & T8 \\
& D9 \\
& D10 \\
& D11 \\
& K12 \\
& K13 \\
& K14 \\
\hline
\end{tabular}

\section{Cell morphology}

Cell shape of the strains were cocci, rod, and short rod whereas cell arrangements were single, paired, tetrad, chain, and scattered; all of the isolated strains were Gram positive except two; 7 isolates were non-motile and 8 were motile. Detail results for cell morphology and Gram reaction are presented in Table 2.

Biochemical characterization of the isolates

Results of physiological and biochemical tests are presented in Table 3. Seven of the isolates were facultative anaerobes and 5 were strictly aerobes. All bacterial samples showed positive results for both gelatin liquefaction and catalase tests and negative results for both indole formation and deamination of phenylalanine. Six samples showed positive and nine showed negative results for starch hydrolysis whereas nine showed positive and 6 showed negative results for oxidase tests. Among the 15 samples 8 showed positive and 7 showed negative results for MR test. Eleven isolates gave negative results and 4 were positive for VP test whereas 11 were positive and 4 were negative for the test of acid production from D-Glucose. All samples showed negative results in gas production from D-Glucose.

Conventionally Identified bacteria

Considering all observed characters of the isolated organisms, identification of Gram positive bacteria was done following Bergey's Manual of Systematic Bacteriology (Vol. 2) ${ }^{9}$ and the results are presented in Table 4. The isolated organisms showed some minor differences in biochemical characters from those cited in that text.

Table 2. Morphological characteristics and Gram reaction of bacterial isolates

\begin{tabular}{|c|c|c|c|c|c|c|c|c|c|c|c|c|c|c|c|}
\hline \multirow{2}{*}{ 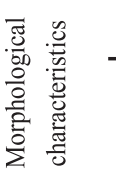 } & \multicolumn{15}{|c|}{ Bacterial isolates } \\
\hline & E1 & E2 & E3 & E4 & $\mathrm{T} 5$ & T6 & $\mathrm{T} 7$ & $\mathrm{~T} 8$ & D9 & D10 & D11 & K12 & K13 & K14 & K15 \\
\hline Form & Circular & Circular & Circular & Circular & Circular & Circular & Circular & Circular & Circular & Circular & Circular & Circular & Circular & Circular & Circular \\
\hline Elevation & Convex & Effuse & Effuse & Convex & $\begin{array}{l}\text { Umbo - } \\
\text { nate }\end{array}$ & Effuse & Convex & Effuse & Convex & Convex & Effuse & Effuse & Convex & Convex & Effuse \\
\hline Margin & Erose & $\begin{array}{l}\text { Undu - } \\
\text { late }\end{array}$ & Entire & Regular & $\begin{array}{l}\text { Undu - } \\
\text { late }\end{array}$ & Entire & Entire & Entire & Entire & Undulate & Undulate & Undulate & Entire & Entire & Erose \\
\hline Surface & $\begin{array}{c}\text { Concentr } \\
\text { ic }\end{array}$ & Smooth & Smooth & Smooth & Smooth & Smooth & Smooth & Smooth & Rough & Smooth & Smooth & Smooth & Smooth & Smooth & Smooth \\
\hline Color & White & White & $\begin{array}{c}\text { Off } \\
\text { White }\end{array}$ & Yellow & White & Brown & Brown & $\begin{array}{c}\text { Off } \\
\text { White }\end{array}$ & $\begin{array}{c}\text { Off } \\
\text { White }\end{array}$ & $\begin{array}{c}\text { Off } \\
\text { White }\end{array}$ & $\begin{array}{c}\text { Off } \\
\text { White }\end{array}$ & White & $\begin{array}{l}\text { Light } \\
\text { Pink }\end{array}$ & $\begin{array}{l}\text { Light } \\
\text { Pink }\end{array}$ & Orange \\
\hline $\begin{array}{l}\text { Shape and } \\
\text { arrange - } \\
\text { ment of } \\
\text { cells }\end{array}$ & $\begin{array}{l}\text { Rod, } \\
\text { rounded } \\
\text { end, } \\
\text { occur in } \\
\text { chain }\end{array}$ & $\begin{array}{l}\text { Rod, } \\
\text { rounded } \\
\text { end, } \\
\text { occur in } \\
\text { chain }\end{array}$ & $\begin{array}{l}\text { Rod, } \\
\text { rounded } \\
\text { end, } \\
\text { occur in } \\
\text { chain }\end{array}$ & $\begin{array}{l}\text { Cocci, } \\
\text { rounded } \\
\text { end, } \\
\text { occur in } \\
\text { tetrads }\end{array}$ & $\begin{array}{l}\text { Rod, } \\
\text { rounded } \\
\text { end, } \\
\text { occur in } \\
\text { chain }\end{array}$ & $\begin{array}{l}\text { Rod, } \\
\text { rounded } \\
\text { end, } \\
\text { occur in } \\
\text { single }\end{array}$ & $\begin{array}{l}\text { Short } \\
\text { Rod, } \\
\text { rounded } \\
\text { end, } \\
\text { occur in } \\
\text { single }\end{array}$ & $\begin{array}{l}\text { Rod, } \\
\text { rounded } \\
\text { end, } \\
\text { occur in } \\
\text { chain }\end{array}$ & $\begin{array}{l}\text { Short } \\
\text { Rod, } \\
\text { rounded } \\
\text { end, } \\
\text { occur in } \\
\text { single }\end{array}$ & $\begin{array}{l}\text { Rod, } \\
\text { rounded } \\
\text { end, } \\
\text { occur in } \\
\text { chain }\end{array}$ & $\begin{array}{l}\text { Rod, } \\
\text { rounded } \\
\text { end, } \\
\text { occur in } \\
\text { chain }\end{array}$ & $\begin{array}{l}\text { Rod, } \\
\text { rounded } \\
\text { end, } \\
\text { occur in } \\
\text { chain }\end{array}$ & $\begin{array}{l}\text { Rod, } \\
\text { rounded } \\
\text { end, } \\
\text { occur in } \\
\text { chain }\end{array}$ & $\begin{array}{l}\text { Rod, } \\
\text { rounded } \\
\text { end, } \\
\text { occur in } \\
\text { chain }\end{array}$ & $\begin{array}{l}\text { Short } \\
\text { Rod, } \\
\text { rounded } \\
\text { end, } \\
\text { occur in } \\
\text { single }\end{array}$ \\
\hline Motility & + & + & - & - & + & - & - & - & - & - & + & + & + & + & + \\
\hline $\begin{array}{c}\text { Gram } \\
\text { reaction }\end{array}$ & + & + & + & + & + & + & - & + & - & + & + & + & + & + & + \\
\hline
\end{tabular}


Table 3. Biochemical characteristics of bacterial isolates

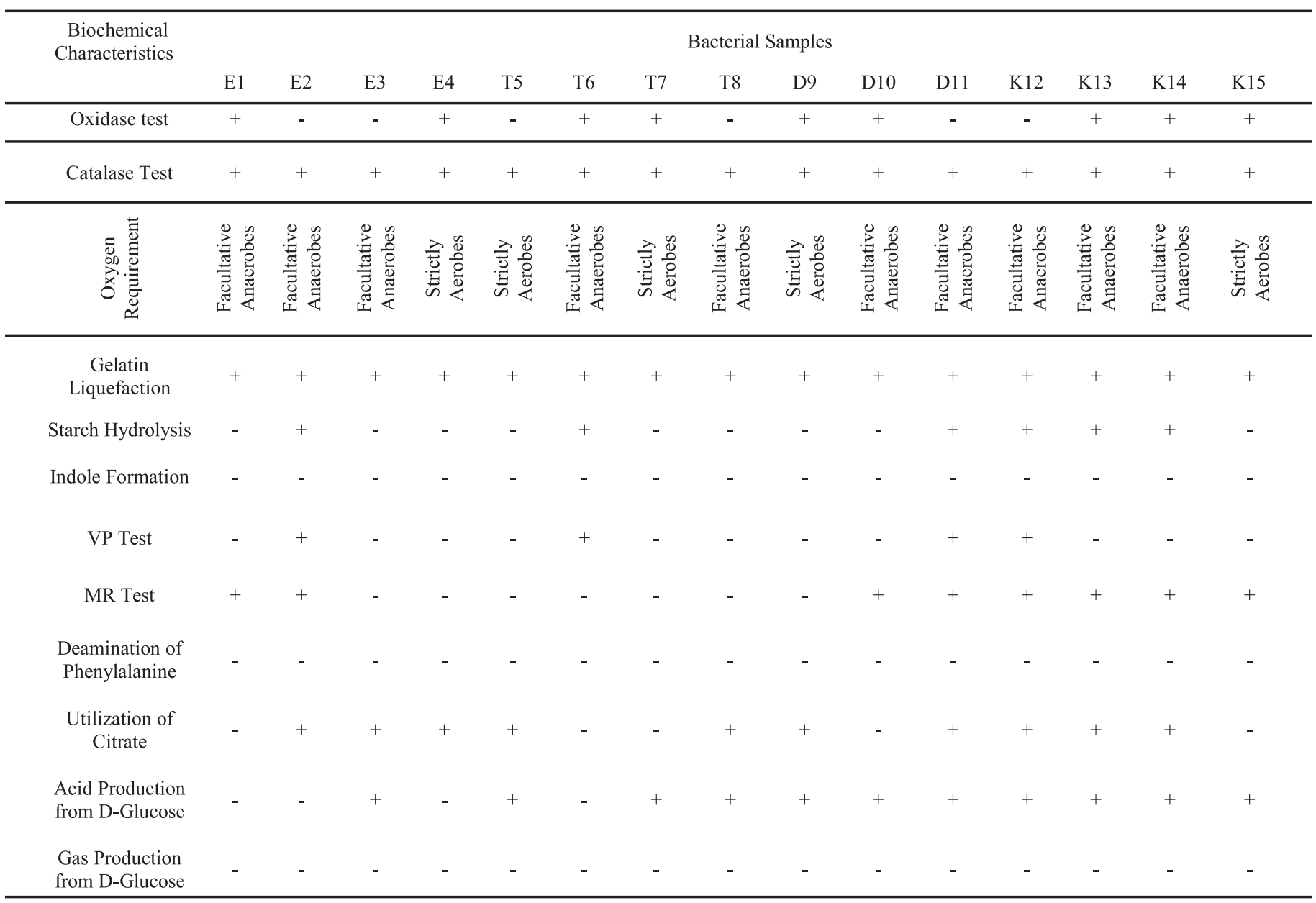

Table 4. Name of the identified bacteria

\begin{tabular}{ll}
\hline Isolates & Name of the identified isolates \\
\hline E1 & Bacillus lentus \\
E2 & Bacillus cereus \\
E3 & Bacillus pumilus \\
E4 & Micrococcus luteus \\
T5 & Bacillus firmus \\
T6 & Bacillus pocheonensis \\
T7 & Pseudomonas pseudoalcaligenes \\
T8 & Bacillus megaterium \\
D9 & Pseudomonas pseudoalcaligenes \\
D10 & Bacillus amyloliquefaciens \\
D11 & Bacillus cereus \\
K12 & Bacillus cereus \\
K13 & Bacillus subtilis \\
K14 & Bacillus subtilis \\
K15 & Bacillus globisporus \\
\hline
\end{tabular}

Identification of bacteria based on PCR and 16S rRNA gene sequencing analysis

Eight previously selected metal tolerant bacterial isolates were used for further confirmation test by PCR and 16S rRNA gene sequencing. The most closely related sequences were found using the BLAST programs against similar sequences in the NCBI databank and isolate E4 was affiliated to Micrococcus luteus strain P4_3 (99\% similarity), isolate T6 to Bacillus pocheonensis strain TR2-6 (99\% similarity), isolate T8 to Bacillus megaterium strain H2 (99\% similarity), isolate D10 to Bacillus amyloliquefaciens strain SCSAAB0007 (99\% similarity), isolates D11 to Bacillus cereus isolate PGBw4 (99\% similarity), isolate K12 to Bacillus cereus strain ES-4a1 (99\% similarity), isolate K13 to Bacillus subtilis strain 1320 (99\% similarity), isolate K14 to Bacillus subtilis strain DP14 (99\% similarity).

\section{Determination of MTC against Chromium and Cadmium}

The eight strains selected as heavy metal tolerant bacteria were used for evaluation of MTC. The MTC of all the bacterial strains against $\mathrm{Cr}^{6+}$ and $\mathrm{Cd}^{2+}$ have shown that the strains were capable of growing at high concentrations of heavy metal ions in nutrient broth and the results of the experiments are given in Table 5 . The microbial load decreased with the increase in concentration of heavy metals indicating toxic effect of the heavy metals on the growth of microorganisms. 
Table 5. Maximum Tolerable Concentrations (MTC) against Chromium $\left(\mathrm{Cr}^{6+}\right)$ and Cadmium $\left(\mathrm{Cd}^{2+}\right)$ of each bacterium cultured in nutrient broth

\begin{tabular}{llcc}
\hline Isolates & Identified Bacterial strain & $\begin{array}{c}\text { MTC against Cr} \\
\text { in Nutrient broth }\end{array}$ & $\begin{array}{c}\text { MTC against Cd }{ }^{2+}\left(\mu \mathrm{g} / \mathrm{ml}^{6}\right) \\
\text { in Nutrient broth }\end{array}$ \\
\hline E4 & Micrococcus luteus strain P4_3 & 600 & 50 \\
T6 & Bacillus pocheonrncis strain TR2-6 & 250 & 120 \\
T8 & Bacillus megaterium strain H2 & 800 & 150 \\
D10 & Bacillus amyloliquefaciens strain SCSAAB0007 & 1000 & 30 \\
D11 & Bacillus cereus isolate PGBw4 & 1250 & 30 \\
K12 & Bacillus cereus strain ES-4a1 & 1250 & 75 \\
K13 & Bacillus subtilis strain 1320 & 950 & 75 \\
K14 & Bacillus subtilis strain DP14 & 1000 & 50 \\
\hline
\end{tabular}

\section{Discussion}

Sampling sites were selected with the aim to isolate metal tolerant bacteria for which the best option was to locate metal contaminated sites. Uncontaminated sites were also selected to evaluate the tolerable limits of heavy metals of common soil bacteria. Bacteria exposed to high levels of heavy metals in their environment have adapted to this stress by developing various resistance mechanisms which could be utilized for detoxification and removal of heavy metals from polluted environment ${ }^{17}$. However, the ability of microorganisms to grow in the presence of relatively high metal ion concentrations is found in a wide range of microbial groups and species, including those from non-polluted sites and not in all cases is any adaptation necessary ${ }^{18}$. Such resistance mechanisms are the basis for the use of microorganisms in bioremediation approaches.

The current study revealed that heavy metal tolerant bacteria were isolated from both contaminated and uncontaminated soils and eight Gram positive bacteria showed the same pattern of metal tolerance against $\mathrm{Cr}^{6+}$ and $\mathrm{Cd}^{2+}$ in the order of $\mathrm{Cr}^{6+}>$ $\mathrm{Cd}^{2+}$ according to the values of MTC. Hence, $\mathrm{Cr}^{6+}$ was found to be more tolerable metal ion whereas $\mathrm{Cd}^{2+}$ appeared to be highly toxic to the bacterial strains. Among eight bacteria maximum tolerance to $\mathrm{Cr}^{6+}$ was shown by Bacillus cereus isolate PGBw4 (D11) isolated from agricultural field of Dhamrai and Bacillus cereus strain ES-4a1 (K12) isolated from agricultural soil of Kushtia showing growth up to $1250 \mu \mathrm{g} / \mathrm{ml}$ and maximum tolerance to $\mathrm{Cd}^{2+}$ was shown by Bacillus megaterium strain H2 (T8) isolated from tannery area showing growth up to 150 $\mu \mathrm{g} / \mathrm{ml}$. Besides, minimum tolerance to $\mathrm{Cr}^{6+}$ was shown by Bacillus pocheonensis strain TR2-6 (T6) isolated from tannery area showing growth up to $250 \mu \mathrm{g} / \mathrm{ml}$ and minimum tolerance to $\mathrm{Cd}^{2+}$ was shown by Bacillus amyloliquefaciens strain SCSAAB0007 (D10) and Bacillus cereus isolate PGBw4 (D11) isolated from agricultural field of Dhamrai showing growth up to $30 \mu \mathrm{g} / \mathrm{ml}$.

The results showed that different bacterial strain of same species could show different MTC to heavy metals. It might be due to variation in genetic level since metal resistance mechanisms of bacteria are sometimes gene-regulated. The order of tolerance to $\mathrm{Cr}^{6+}$ of identified all Gram positive bacterial strain of Micrococcus and Bacillus spp. is B. cereus $>B$. amyloliquefaciens $>B$. subtilis $>B$. megaterium $>$ Micrococcus luteus $>B$. pocheonensis and the order of tolerance to $\mathrm{Cd}^{2+}$ is B. megaterium $>B$. pocheonensis $>B$. subtilis $>$ Micrococcus luteus $>$ B. amyloliquefaciens $>B$. cereus. In this study it was found that all Gram positive bacteria showed higher $\mathrm{Cr}^{6+}$ tolerance. It was reported that Gram-positive bacteria were more $\mathrm{Cr}^{6+}$ tolerant than Gram-negative bacteria ${ }^{19}$. This was also reported by other authors who widely documented the high presence of tolerant Gram-positive bacteria in soil polluted with heavy metals ${ }^{20}$. Other results have also reported that the diversity of Bacillus was greatest in contaminated soil ${ }^{21}$.

\section{Conclusion}

Among the genera of Bacillus, Pseudomonas, and Micrococcus identified in the present study Bacillus was found as the most heavy metal tolerant bacteria having high degree of tolerance against Chromium and Cadmium both in contaminated and uncontaminated soils whereas others were relatively susceptible. It indicates their easy survival capacity in metal polluted environment. Hence Bacillus will be common in microbial composition of uncontaminated agricultural soils and will regulate the transformation mechanisms of those soils though soils are being contaminated with heavy metals as because soil transformation processes are largely dependent on relevant microbial population. The abundance of Bacillus was possibly due to the spore structure in the Bacilli group which increases its power of uptake and resistance against the metals. Evaluation of heavy metal tolerance in bacteria may provide a great insight into application of processes in bioremediation. Bacterial tolerance to heavy metals may be a fall out of the detoxification mechanisms intrinsic to the bacteria. Future studies should investigate heavy metal tolerance in bacteria in industrially contaminated soil ecosystems and may demonstrate its utility in detecting environmental pollution by heavy metals, transformation of nutrients in soils, and for element recovery and environmental protection by economically feasible and technologically efficient means. 


\section{Reference}

1. Cheng S. 2003. Heavy metal pollution in China: origin, pattern and control. Environ Sci and Pollution Res. 10: 192-198.

2. Chung J, Nerenberg R and Rittmann BE. 2006. Bio-reduction of soluble chromate using hydrogen based membrane bioflim reactor. Water Research 40: $1634-1642$.

3. Thacker U, Parikh R, Shouche Y and Madamwar D. 2006. Hexavalent chromium reduction by Providencia sp. Process Biochem. 41: 1332-1337.

4. Tang XY, Zhu YG, Cui YS, Duan J and Tang L. 2006. The effect of ageing on the bioaccessibility and fractionation of cadmium in some typical soils of China. Environment Int. 32: 682-689.

5. Pumpel T, Pernfub B, Pigher B, Diels L and Schinner F. 1995. A rapid screening method for the isolation of metal-accumulating microorganisms. J Indust Microbiol. 14: 213-217.

6. Sibly RM and Shirley MD. 1999. Genetic basis of a between environment trade off involving resistance traits in Azotobacter chroococum isolated from rhizospheric soil. Biores Technol. 86: 7-13.

7. Greenberg EL, Clerceri S and Eaton AD. 1980. Standard methods for the examination of water and wastewater, $18^{\text {th }}$ edn. Am Publ Health Assoc. Washington D. C.

8. Mergeay M, Nies D, Schlegel HG, Gerits J, Charles P and Van Gijsegem F. 1985. Alcaligenes eutrophus CH34 is a facultative chemolithotroph with plasmid bound resistance to heavy metals. J Bacteriol. 3: 691-698.

9. Sneath PHA, Mair NS, Sharpe ME and Holt JG. 1986. Bergey's manual of systematic bacteriology, $9^{\text {th }}$ edn. Williams and Wilkins. Baltimore, London 2: 1599.
10. SAB (Society of American Bacteriologist). 1957. Manual of microbiological methods, pp 315. McGraw Hill Book Company Inc, New York.

11. Cappuccino JG and Sherman N. 2005. Microbiology: A Laboratory manual, $7^{\text {th }}$ edn, pp 1-453. Dorling Kindersley (India), Pvt Ltd, New Delhi, India.

12. Collins CH and Lyne PM. 1984. Microbiological methods, $5^{\text {th }}$ edn, pp 446. Butterworth and Co. (Publisher) Ltd, London.

13. Claus GW. 1995. Understanding Microbes, $4^{\text {th }}$ edn, pp 547. W H Freman and Company, New York.

14. Pelczar MJJ and Reid RD. 1958. Pure cultures and growth characteristics. In Microbiology, pp 76-84. McGraw-Hill Book Company, New York.

15. Robert SB, Murray EGD and Smith NB. 1957. Bergey's Manual of Determinative Bacteriology, $7^{\text {th }}$ edn. The Williums \& Wilkins company, USA.

16. Pepper IL and Gerba CP. 2005. Environmental Microbiology, $2^{\text {nd }}$ edn. Elsevier Academic Press publications. Burlington, MA 01803, USA.

17. Ahmed NA, Nawaz, and Badar U. 2005. Screening of copper tolerant bacterial species and their potential to remove copper from the environment. Bulletin of Environmental and Contamination Toxicology 74: 219-226.

18. Gadd GM. 1990. Heavy metal accumulation by bacteria and other microorganisms. Journal Experientia. 46: 834-840.

19. Viti C and Giovannetti L. 2001. The impact of chromium contamination on soil heterotrophic and photosynthetic microorganisms. Ann Microbiol. 51: 201-213.

20. Konopka A, Zakharova T and Bischoff M. 1999. Microbial biomass and activity in lead contaminated soil. Appl Environ Microbiol. 65: 2256-2259.

21. Sagordoy MA and Salerno CM. 1983. Number, distribution and characterization of heterotrophic bacteria in some Argentine soils. Ann Edafol Agrobiol. 42: 2069-2081. 